WPS2915

\title{
Federal Politics and Budget Deficits: Evidence from the States of India
}

\author{
Stuti Khemani \\ Development Research Group \\ World Bank, 1818 H Street, N.W. \\ Washington, DC 20433 \\ skhemani@worldbank.org
}

World Bank Policy Research Working Paper 2915, October 2002

The Policy Research Working Paper Series disseminates the findings of work in progress to encourage the exchange of ideas about development issues. An objective of the series is to get the findings out quickly, even if the presentations are less than fully polished. The papers carry the names of the authors and should be cited accordingly. The findings, interpretations, and conclusions expressed in this paper are entirely those of the authors. They do not necessarily represent the view of the World Bank, its Executive Directors, or the countries they represent. Policy Research Working Papers are available online at http://econ.worldbank.org.

Support from the World Bank's Research Committee is gratefully acknowledged. I also thank Gunnar Eskeland, Stephen Howes, Shahrokh Fardoust, Edgardo Favaro, Manuela Ferro, Jonathan Rodden, and participants of the World Bank Economists Forum, April 30, 2002, for helpful comments. 


\begin{abstract}
This paper tests two predictions implied by models of the common-pool game in federations where subnational governments are more likely to have higher deficits because they do not internalize the macroeconomic effects of fiscal profligacy. The first is that subnational governments that belong to the same political party as the central government have lower spending and deficits because they are more likely to be influenced to internalize the macroeconomic effects of additional local spending; and the second is that subnational governments that are more dependent on intergovernmental transfers have higher spending and deficits. We find that in 15 major states of India over the period 19721995, states in fact have substantially higher spending and deficits (higher by about 10 percent of the sample average) when their government belongs to the same party as that governing at the center; and that intergovernmental grants tend to have a counter-intuitive negative effect on spending and deficits. The additional deficit of affiliated states is financed almost entirely by additional loans from the central government (as opposed to the market) leading to our interpretation that similar political considerations influence the distribution of deficits across states as they do other intergovernmental grants. We argue that the evidence from India, contrasted with broader international evidence, indicates that the effect of fiscal institutions in a federation is sensitive to underlying political incentives. This underscores the overall importance of political institutions in determining the consolidated government deficit, relative to specific rules of intergovernmental transfers.
\end{abstract}




\section{Introduction}

There is increasing concern in policy circles that developing countries that are rapidly decentralizing are exposed to the risk of macroeconomic instability due to growing fiscal deficits and soft budget constraints at subnational levels. While similar concerns exist for developed countries as well, the risk is perceived as exacerbated for developing countries because of lower potential revenue bases at local levels, higher dependence on federal transfers, and poor quality of legal institutions. The concern gains credence largely from individual case studies of sizable and persistent subnational deficits in federal countries like Argentina, Brazil, and India (Rodden, Eskeland, and Litvack 2001, World Bank 1999) and the theoretical and intuitive link between fiscal deficits and decentralization.

This link lies in a political economy perspective of fiscal federalism in which the geographical distribution of costs, benefits, and decisionmaking power over public expenditures leads to a "common pool" problem akin to the classic theory of distributive politics (Weingast, Shepsle, and Johnsen 1981, Inman and Fitts 1990, Aizenman 1998). If subnational governments make spending decisions, and are financed by transfers from the national government, which raises taxes, then the resulting amount of total government spending will be inefficient, because local authorities do not fully internalize the effects of their spending decisions on the consolidated government budget.

Within this framework, variations in political and institutional relations between the national and different subnational governments will have differential effects on the common pool problem, and hence on individual subnational fiscal policies. Jones, Sanguinetti, and Tommasi (2000) develop two hypotheses based on the common pool game for the impact of federal-provincial relations on spending by provincial governments in Argentina-one, provinces with higher federal transfers will have higher spending; and two, provinces where the governor is from the same party as the President will have lower spending. The first hypothesis is argued to result from the greater de-coupling of tax and spending decisions in provinces that are more favored by federal transfers. The second hypothesis follows the argument that the provincial governor who is politically affiliated with the national President will be more likely to internalize the effect of spending an additional unit of national resources due to internal party discipline. The empirical evidence from the Argentine provinces is consistent with both hypotheses. Similar evidence for the impact of intergovernmental transfers has been found for German provinces (Rodden 2000), the U.S. states (Rogers and Rogers 2000) and in cross-country analysis (Rodden 2002). This paper estimates the effect of political and fiscal relations between the national and provincial governments on provincial fiscal deficits in another large federation of the developing world, 
India, to examine whether the above implications of the common pool problem holds under an arguably different model of federal politics.

Ter-Minassian (1997), Rodden, Eskeland, and Litvack (2001) and Inman (2001) study the mechanisms and institutions that support fiscal discipline, or indiscipline, at the subnational level. The underlying story is essentially one of errant local governments yielding to the temptation of shifting their own budgetary costs onto the central government. Fiscal profligacy by subnational governments is (unwillingly) rewarded by the national government as it is unable to commit in advance to a policy of "no bailouts" when a local jurisdiction is in trouble. Specific deficit bailouts and general federal transfers both "soften" the local government's budget constraint and lead to inefficient resource allocation (Inman 2001). The national government is thus vulnerable to strategic manipulation by local governments because of its inability to commit to a "no-bailout" policy.

The above story of a center vulnerable to subnational fiscal profligacy is based upon models of electoral competition where the national government is elected from national constituencies and evaluated on the basis of macroeconomic outcomes. Thus, the national government has more powerful incentives for fiscal conservatism than each subnational government. In this model, greater fiscal decentralization would be associated with higher deficits, other things being equal (Weingast, Shepsle, and Johnsen 1981). An implication of this model tested by Jones, Sanguinetti, and Tomassi (2000), as indicated above, is that subnational governments that are politically affiliated with the center will be less likely to engage in opportunistic behavior, and should have lower deficits.

Institutions of fiscal decentralization may assist in providing perverse incentives for subnational expenditures by increasing the disconnect between tax and spending decisions. Specifically, when subnational governments are largely dependent on intergovernmental transfers rather than locally generated revenues, and where transfers are designed to assist fiscally disadvantaged states, the fiscal institutions may facilitate over-borrowing and overspending by subnational governments because the central government finds it harder to commit to a "no-bailout" policy (Rodden 2002). Indian fiscal federalism is indeed characterized by vertical fiscal imbalance, where the states have undertaken 50-60 percent of total government spending in the last decade, of which 30-40 percent has been financed by central transfers (Rao and Singh 2000). Intergovernmental transfers in India have also long been assumed to provide perverse incentives to state governments because of the so-called "gap-filling" approach where some transfers are directed to cover the discrepancy between planned expenditures and expected revenues (Rao 1998, McCarten 2001).

In this paper we use variation in party affiliation and intergovernmental grants across 15 major states of India over a 24-year period from 1972-95 to test the above implications. 
Contrary to the expectations outlined above we find that in periods when a state government belongs to the same party as that at the center the state has higher than average fiscal deficits, and greater transfers are correlated with lower spending and lower deficits. The partisan effect is large, with deficits in affiliated states being 10 percent higher on average than deficits in non-affiliated states. Additional evidence indicates that among affiliated states, deficits are greater in those states where the ruling party controls a smaller proportion of seats to the national legislature, and thus states which may be politically pivotal to gain a majority in the national legislature.

We argue that this evidence is consistent with a particular model of federal politics that exists in India, consisting of electoral competition amongst different political parties where voters are responsive to local public spending and tend to vote along party lines. We find that the higher deficits of affiliated states is entirely financed by greater loans from the central government, as opposed to other forms of market debt, and interpret this as evidence that similar political considerations drive the distribution of deficits across subnational governments as they do other intergovernmental grants. This political effect on deficits is consistent with recent evidence on the political determinants of systematic channels of intergovernmental transfers to the states in India (Dasgupta, Dhillon, and Dutta 2001, Khemani 2002, and Rao and Singh 2000).

The contrast of the Indian experience versus other international evidence suggests that the effect of institutions of fiscal decentralization on subnational spending and deficits is dependent on the nature of the political incentive environment. This analysis thus provides a rationale to somewhat dissociate the problem of subnational fiscal deficits from the institutions of fiscal decentralization (such as rules of intergovernment fiscal transfers), and renew focus on general political determinants of deficits, or on institutions of political decentralization. We develop a simple model where the counter-intuitive effects of political partisanship and intergovernment transfers on subnational deficits in India can exist in equilibrium under specific electoral institutions and voting behavior. The empirical evidence provided here may motivate the development of a more general theory, and subsequent crosscountry empirical testing, of the sensitivity of the impact of fiscal decentralization instruments to variation in federal political institutions around the world.

There exists a substantial macroeconomic literature on the political and institutional determinants of fiscal deficits of the national government (see Alesina and Perotti 1995, 1996 for excellent surveys and von Hagen, 1992). Some of this political and institutional analysis carries over to the case of subnational governments, with a political game played within subnational governments between different agents, in addition to any federal game. Poterba (1994) and Alt and Lowry (1994) examine the effect of divided governments on fiscal policy in the American states, and find that adjustment to fiscal shocks is slower in states with 
different parties controlling the state legislature and executive. Poterba (1996) provides a survey of the impact of legislated budgetary institutions on state fiscal policy—states with balanced budget rules adjust faster to fiscal shocks. However, this strand of literature on budget deficits did not study the impact of broader political and constitutional institutions like electoral rules and political regimes.

The empirical evidence for the Indian states shows that political institutions governing relations between the central and state governments is a significant determinant of subnational deficits, and provides additional motivation for delving deeper into the political incentives driving budget deficits in a federation. Partisan affiliation between the central and state governments in fact stands out as the only significant political determinant of subnational deficits, to the exclusion of other plausible political and institutional determinants that have been tested in the received literature, such as election cycles, fragmented legislatures, and budgetary institutions.

In the next section we lay out a theoretical framework for the impact of federal political institutions on sub national deficits, that motivates our empirical specification and interpretation of the evidence. Section 3 describes the empirical methodology and the data, and presents the results. Section 4 concludes.

\section{Analytical framework}

Variation in subnational deficits and spending, after controlling for basic economic conditions that are fundamental determinants of deficits, can be thought of as the result of strategic interaction between central and subnational governments. We adopt this approach here and develop a simple game theoretic framework to examine the role of federal political relations and intergovernmental transfers in determining subnational deficits. The basic analytical framework used here is drawn from Inman's (2001) characterization of fiscal bargaining between local and national governments. Ultimately, the relative significance of political affiliation and intergovernmental transfers in determining subnational deficits is an empirical question, and the primary focus of this study.

Figure 1 lays out the sequential game between the provincial and central government. The "status-quo" of this game is the outcome of the central government's determination of overall resource allocation to the provincial governments to optimize its political objectives. The provincial government deficit is determined at the nationally optimal level $(d)$, which is fully funded by the central government through loans $(l)$. However, the provincial government, as the first mover in this game, can undertake an action of over-spending and increasing its deficit ( $\Delta d$ ) beyond the optimal level that is financed systematically by central loans. The central government may respond to this additional deficit by either financing it 
through additional loans ( $\Delta l$ ) or leaving the local government to fund its additional deficit through fiscal retrenchment, raising additional taxes or lowering spending. The payoffs to the central and provincial governments may be expressed as the difference between benefits and costs for each pair of actions undertaken.

\section{Figure 1.}

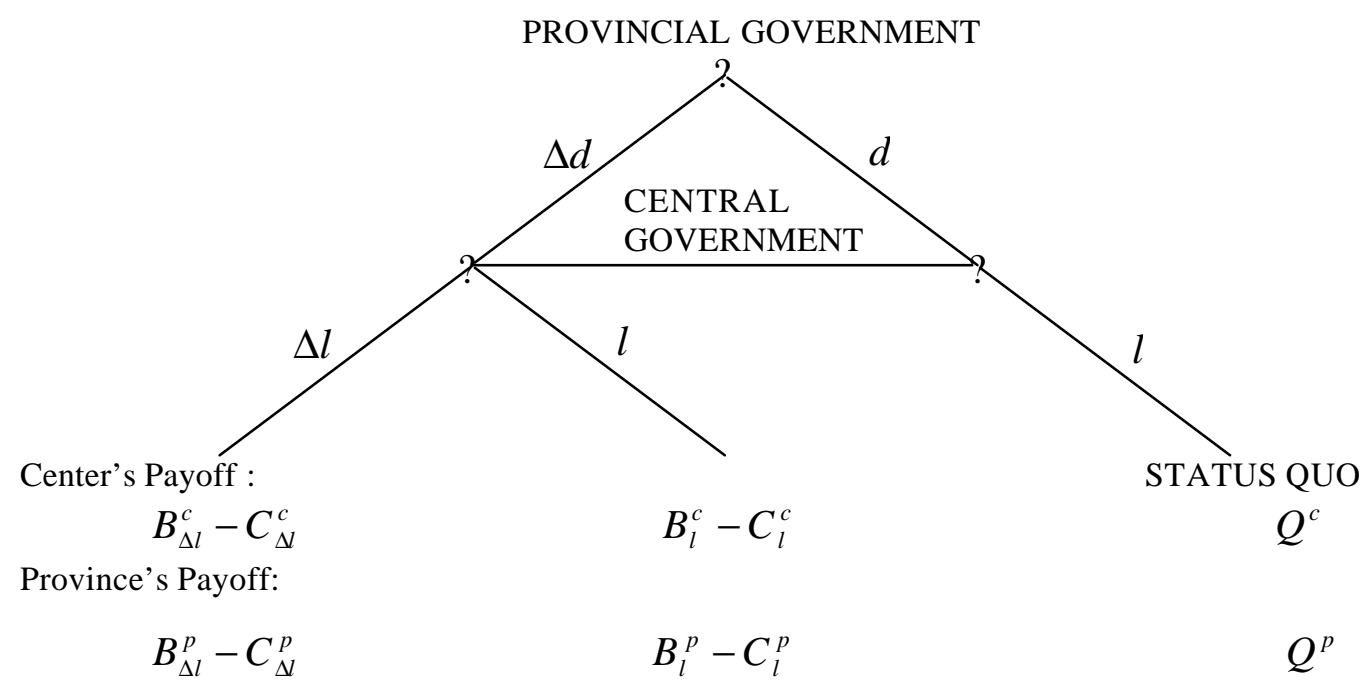

Note that given our definition of the status quo as the centrally determined optimal solution, we have $B_{\Delta l}^{c}-C_{\Delta l}^{c}<Q^{c}$. However, the equilibrium of this game could be $(\Delta d, \Delta l)$, that is where the local government over-spends and central government provides additional loans to fund the additional deficit, if the following conditions are satisfied:

$$
\begin{aligned}
& B_{\Delta l}^{c}-C_{\Delta l}^{c}>B_{l}^{c}-C_{l}^{c} \\
& B_{\Delta l}^{p}-C_{\Delta l}^{p}>Q^{p} \\
& B_{l}^{p}-C_{l}^{p} \leq Q^{p}
\end{aligned}
$$

The recent literature on institutions of fiscal federalism in a cross-section of countries implies that these conditions for the equilibrium of $(\Delta d, \Delta l)$ are more likely to hold in countries characterized by greater dependence of provincial governments on intergovernmental transfers. In this "common pool" approach, the reliance on central transfers would lead to a payoff structure such that condition (1) holds, and therefore the central 
government cannot credibly commit in advance to a "no-bailout" policy. The argument is usually along the following lines: voters distinguish between the role of provincial and central governments, holding the former responsible for the provision of local public goods and the latter for general macroeconomic stability and insurance from unexpected shocks. However, they are unable to perfectly distinguish whether fiscal problems and economic hardships are due to unsustainable actions taken by the provincial government or inaction by the central government during times of negative economic shocks. Hence, in the event of local fiscal indiscipline the central government is not likely to withhold a bailout because that would be politically costly. Knowing this, local governments have incentives to over-spend. By this same argument, within countries provinces that are more dependent on central transfers would be more likely to have higher spending and deficits.

Within countries the conditions for this equilibrium are also more likely to hold the greater is the political bargaining power of a provincial government, leading to a correlation between the level of provincial deficits and spending and indicators of provincial bargaining power. Hence, large provincial governments with a large vote-base or provinces with a pivotal vote-base are more likely to receive additional central funds to finance additional spending. Furthermore, large provinces with significant fiscal externalities for the rest of the country may be "too big to fail" and also likely to have higher spending and deficits financed by central loans.

The main question of interest for our purposes here is that controlling for size and political representation, how does spending and deficits vary across provinces with different political affiliations and varying degrees of dependence on intergovernmental transfers? Variation in political affiliation across provinces could be correlated with variation in provincial deficits because of the role affiliation plays in the central determination of $(d, l)$, and not as a result of strategic fiscal bargaining between central and provincial governments. Khemani (2002) develops a model of central resource allocation where the solution is characterized by greater central transfers to politically affiliated states because the center gains political advantage in these states. Central loans, or central guarantees of market loans, are instruments of resource transfer which would thus also favor affiliated states according to the model, implying higher $(d, l)$ for affiliated as opposed to unaffiliated states.

In this section we focus on the conditions under which fiscal bargaining between the center and provinces may lead to higher subnational deficits. We outline a model of political relations in a federation to generate payoff functions for the center-province game described above and examine the conditions under which $(\Delta d, \Delta l)$ would be an equilibrium, leading to variation in deficits across provinces as a result of different conditions of center-province bargaining. 
We model federal politics as electoral competition between rival political parties with representation in both central and provincial governments. ${ }^{1}$ Political parties $A$ and $B$ compete for seats to the national and state legislatures, and the party with a majority of seats at each level gets to form the executive government at that level. Each province is divided into electoral districts for both the state and the national legislature. Voters hold the provincial governments responsible for providing local public goods and the central government responsible for macroeconomic stability and insurance against regional economic shocks. Good (bad) performance of provincial governments leads to positive (negative) spillovers for the political party even at the national level. Conversely, performance of a political party at the national level has spillover effects in provincial elections. The objective of political parties at each tier of government is to maximize representation in the elected legislature. ${ }^{2}$

Without loss of generality, let party $A$ be the incumbent party at the federal government with majority seats in the national legislature. Among the provinces in the federation, a subset $\mathfrak{R}_{A}$ have incumbents belonging to the party $A$ and are affiliated with the center, whereas the remaining subset $\mathfrak{R}_{B}$ have incumbents belonging to the party $B$ and are therefore unaffiliated with the center.

Let $S_{a}^{c}$ and $S_{u}^{c}$ denote the number of seats the central government wins on average in affiliated and unaffiliated provinces, and let $S_{a}^{p}$ and $S_{u}^{p}$ denote the typical number of seats the provincial governments win. The objective of each tier of government is to maximize the number of seats in the legislature, and the payoff functions are therefore in terms of gains and losses in electoral districts. Hence, we have the "status quo" payoffs for affiliated states, $\mathfrak{R}_{A}$, as follows:

$$
\begin{aligned}
& Q^{c}=S_{a}^{c} \\
& Q^{p}=S_{a}^{p}
\end{aligned}
$$

\footnotetext{
${ }^{1}$ Treisman (1999) models political decentralization as the interaction between central and local officials in a two-level state, where local officials have the power to accept or reject the center's authority, while the center has coercive capacity to enforce its authority through the use of sanctions. Increasing decentralization in this model is characterized as a reduction in the stock of punishments available to the center to enforce its authority. In this model, the strategic game between the center and the provinces restricts the ability of the center to use instruments of economic reform for fiscal and macroeconomic stability.

${ }^{2}$ In most models of distribution of national resources the objective function is assumed to be the maximization of vote share or vote total, as political parties arguably care about their margin of victory or about having a strong minority presence (Dixit and Londregan 1995, 1996, 1998 and Cox and McCubbins 1986). Snyder (1989) however shows that different empirical predictions for district-level resource allocation are obtained if the objective is to maximize the number of seats won or the probability of winning a majority of seats. Since the analysis undertaken here is at a level of aggregation above the district, we abstract from these finer details in the nature of the political objective function.
} 
and for unaffiliated states, $\Re_{B}$, as;

$$
\begin{aligned}
& Q^{c}=S_{u}^{c} \\
& Q^{p}=S_{u}^{p}
\end{aligned}
$$

Increasing public expenditures allow incumbent political parties to gain additional districts in elections at all levels by extending political patronage to critical coalitions of voters in return for general support for the party. Hence, if an affiliated province in $\mathfrak{R}_{A}$ undertakes additional spending $(\Delta d)$, and the center responds by providing the necessary funds $(\Delta l)$, then the political party $A$ controlling both the center and the province gains some seats from that province's electorate through the provision of local public goods. Let $\delta_{u}^{c}$ and $\delta_{u^{p}}{ }^{p}$ be the additional seats that may be gained for the central and provincial governments in $\mathfrak{R}_{A}$ if the provincial government over-spends and the central government funds the additional deficit.

If party $B$ undertakes additional spending in a provincial government in $\Re_{B}$ that is fully financed by the center, then it gains seats in both the provincial and national legislature, leading to a loss of seats from that province for party $A$ in the national legislature. Therefore, in unaffiliated states in $\Re_{B}$, let $\delta_{u}^{p}$ be the additional seats gained by the provincial government with over-spending, and let $\delta_{u}^{c}$ be the loss of seats for the central government in the national legislature should it bail-out its rival political party.

Therefore, we have:

$$
\begin{aligned}
& \delta_{a}^{c} \geq 0 \text { and } \delta_{a}^{p} \geq 0 \\
& \delta_{u}^{c} \leq 0 \text { and } \delta_{u}^{p} \geq 0
\end{aligned}
$$

Political party $A$ also incurs costs of macroeconomic instability by extending additional loans, above the nationally optimal level $l$, which reduces the well-being of the average voter. Let $\varepsilon^{c}$ and $\varepsilon^{p}$ be the cost incurred by party $A$ in any province in the central and provincial legislatures respectively whenever it undertakes action $\Delta l$.

Therefore, we have:

$$
\varepsilon^{c} \leq 0, \varepsilon^{p} \leq 0
$$

If a provincial government undertakes additional spending which is subsequently not financed by the center, and requires fiscal retrenchment, its party loses credibility and goodwill with the voters. In addition, since voters cannot perfectly distinguish between fiscal irresponsibility of provincial governments and inaction on the part of a central government 
that is responsible for insuring the regions against negative economic shocks, each time unexpected fiscal retrenchment occurs, voters also punish the party in power at the center. If a province in $\Re_{A}$, takes action $\Delta d$, and the center responds with $l$, then party $A$ loses $\mu_{a}^{c}$ in the central legislature and $\mu_{a}^{p}$ in the provincial legislature. Conversely, if a province in $\Re_{B}$, takes action $\Delta d$, and the center responds with $l$, then party $B$ loses $\mu_{u}^{p}$ in the provincial legislature. Party $A$ stands to gain some seats in the national legislature because of the loss of support for party $B$, but also to lose some seats because of voter perception of poor performance in providing regional insurance. Let $\mu_{u}^{c}$ be the net change in seats for party $A$ in the central legislature.

Therefore, we have:

$$
\begin{aligned}
& \mu_{a}^{c}<0 \text { and } \mu_{a}^{p}<0 \\
& \mu_{u}^{c} ? ? 0 \text { and } \mu_{u}^{p}<0
\end{aligned}
$$

In addition, the loss to the central government because of a provincial government's fiscal retrenchment will be greater the greater is the dependence of the provincial government on intergovernmental transfers. With greater dependence on central transfers provincial voters are more likely to hold the central government responsible for their region's well-being, and therefore more likely to punish the center for perceived fiscal mismanagement in their region. Hence, we have:

$$
\begin{gathered}
\frac{d\left|\mu_{a}^{i}\right|}{d T}>0, \text { for } i=c, p, \text { for } \\
\frac{d \mu_{u}^{c}}{d T}<0 \text {, if } \mu_{u}^{c}>0 \\
\frac{d\left|\mu_{u}^{c}\right|}{d T}>0, \text { if } \mu_{u}^{c}<0
\end{gathered}
$$

where $T=$ central transfers.

The payoff functions in a center-province game in $\mathfrak{R}_{A}$ are therefore:

$$
\begin{array}{ll}
B_{\Delta l}^{c}-C_{\Delta l}^{c} & =S_{a}^{c}+\left[\delta_{a}^{c}+\varepsilon^{c}\right] \\
B_{l}^{c}-C_{l}^{c} & =S_{a}^{c}+\mu_{a}^{c}
\end{array}
$$




$$
\begin{array}{ll}
B_{\Delta l}^{p}-C_{\Delta l}^{p} & =S_{a}^{p}+\left[\delta_{a}^{p}+\varepsilon^{p}\right] \\
B_{l}^{p}-C_{l}^{p} & =S_{a}^{p}+\mu_{a}^{p}
\end{array}
$$

whereas the payoff functions in a center-province game in $\Re_{B}$ are the following:

$$
\begin{array}{ll}
B_{\Delta l}^{c}-C_{\Delta l}^{c} & =S_{u}^{c}+\left[\delta_{u}^{c}+\varepsilon^{c}\right] \\
B_{l}^{c}-C_{l}^{c} & =S_{u}^{c}+\mu_{u}^{c} \\
B_{\Delta l}^{p}-C_{\Delta l}^{p} & =S_{u}^{p}+\delta_{u}^{p} \\
B_{l}^{p}-C_{l}^{p} & =S_{u}^{p}+\mu_{u}^{p}
\end{array}
$$

From our assumptions above, the payoff functions from the center-province game in $\mathfrak{R}_{A}$ and in $\mathfrak{R}_{B}$ are independent. Hence, the conditions of equilibrium for the overall game between the center and the two types of provinces in $\mathfrak{R}_{A}$ and $\mathfrak{R}_{B}$ are the same as the equilibrium conditions for isolated center-province games.

For the central government to provide additional loans to affiliated states in equilibrium, we must have the following conditions satisfied:

$$
\begin{aligned}
& \delta_{a}^{c}>\left|\varepsilon^{c}-\mu_{a}^{c}\right| \\
& \delta_{a}^{p}+\varepsilon^{p}>0
\end{aligned}
$$

Condition (11) implies that the gain in seats for the central government due to additional public expenditures by its affiliated political party has to be greater than the absolute difference between the loss in seats due to the costs of macroeconomic instability and the loss in seats due to fiscal retrenchment of the provincial government. Hence, even if the gain in seats due to additional local expenditures is less than the loss in seats due to suboptimal levels of borrowing, $\delta_{a}^{c}>\left|\varepsilon^{c}\right|$, so that the center prefers the status quo $\left(Q^{c}=S_{a}^{c}\right)$ ${ }^{3}$, the center may still be forced to bail-out the provincial government if the loss from provincial fiscal retrenchment $\left(\mu_{a}^{c}\right)$ is high enough (in absolute value). Condition (12) simply states that the provincial government must prefer the outcome with fully funded additional spending than the status quo.

\footnotetext{
${ }^{3}$ This is what we would expect if $(d, l)$ is defined as the centrally determined optimal level of subnational deficits and central loans, given initial economic and political conditions.
} 
For the central government to provide additional loans to unaffiliated states in equilibrium, the following conditions must be satisfied:

$$
\begin{gathered}
\mu_{u}^{c}<0 \\
\left|\mu_{u}^{c}\right|>\left|\delta_{u}^{c}+\varepsilon^{c}\right|
\end{gathered}
$$

Condition (13) needs to be satisfied at a minimum because otherwise we would have $B_{l}^{c}-C_{l}^{c}>B_{\Delta l}^{c}-C_{\Delta}^{c}$, following from (6b) and (7). That is, for $(\Delta d, \Delta l)$ to be an equilibrium in unaffiliated states, the gain to the central political party from its rival party's discomfiture due to fiscal retrenchment has to be less than the direct loss to the central party due to perceived mismanage ment of central transfers. Condition (14) follows from (13) and implies that the loss to the central government in seats from the province's electorate must be greater than the loss in seats due to a bail-out-both directly because of adverse macroeconomic impacts and indirectly because of the gain in popularity of the rival political party.

All of conditions (11)-(14) are more likely to be satisfied when provincial governments are highly dependent on intergovernmental transfers from the center leading to large values (in the absolute) for $\mu_{j}^{i}$, where $i=c, p$ and $j=a, u$. In this case, greater dependence on central transfers may be driving the variation in subnational deficits, as provinces with greater dependence, irrespective of political affiliation, are likely to exact higher political costs on the central government if they are forced to make costly fiscal adjustments. Political affiliation may not account for any of the variation in subnational deficits due to fiscal bargaining.

On the other hand, if provincial voters tend to be very responsive to public expenditures by local governments, and less likely to punish the central government for regional fiscal mismanagement, then conditions (11) and (12) are more likely to hold than conditions (13) and (14). Condition (13) would tend to fail as the central party would be more likely to make a net gain from voter dissatisfaction with the rival party in the province as the latter is forced to make spending cut-backs. Condition (11) is more likely to be satisfied than condition (14) because it requires a smaller value of $\left|\mu_{u}^{c}\right|$ for $j=a, u$. In this case, we would find politically affiliated provinces with higher deficits than unaffiliated provinces because of the greater political bargaining power of affiliated provinces.

The assumptions of the above model are consistent with the received analysis of federal politics in India. India is a parliamentary democracy since the adoption of its constitution in 1950, with direct elections based on universal adult suffrage to the Lok Sabha, 
or the House of the People, the lower house at the national level, and to the Vidhan Sabhas, the individual legislative assemblies at the state level. The political party with majority seats in the national legislature forms the cabinet of ministers and appoints the Prime Minister to lead the executive branch of the national government. Analogous to the national executive, the state executive consists of a cabinet of ministers headed by a Chief Minister and appointed by the majority party in the Vidhan Sabha.

Voters in India are known to vote overwhelmingly along party lines, across state and national elections (Butler, Lahiri, and Roy 1995). Chhibber (1995) and Weiner and Field (1974) suggest that there are limited ideological differences between parties along the lines of economic policy, but rather, party identity is driven by social, ethnic, and regional differences. Electoral competition between these parties has been characterized as revolving around access to the instruments of government and appropriation of public resources by different groups (Chhibber 1995).

Expenditure responsibilities in the Indian federation are largely decentralized to state governments who thus have access to spending instruments with direct impact on people's lives. If a party loses control of a state government it thus loses control over some public instruments to buy political support through patronage. Hence, it is not surprising to note that if a party comes to power in a state (by winning a majority of seats in the state legislature), then in the next national elections that party also tends to win seats to the national legislature from that state. ${ }^{4}$ Hence, additional spending by state governments can be expected to yield benefits in the form of additional seats for the political party in power in the state, in both state and national elections.

Specific electoral institutions in India may also make it more likely that the central government stands to gain more through augmented local expenditure programs than to lose from the overall macroeconomic effects of over-spending and over-borrowing. India's firstpast-the-post voting system is based on contests between individual candidates in singlemember constituencies where the seat is won by the candidate that gets more votes than any other. This simple plurality electoral law in practice implies a very tenuous link between the percentage of popular votes received by a party and the probability of winning the majority of seats in the legislature, because of fragmented electoral competition in each constituency. Butler, Lahiri, and Roy (1995) indicate that once a party crosses a particular threshold in

\footnotetext{
${ }^{4}$ An example from the state of Andhra Pradesh is illustrative in this context. The Congress party lost control of the state government in Andhra Pradesh in the 1983 state elections to a new regional party, the Telegu Desam. In the next national elections in 1984, even though it won an overwhelming majority of seats in the national legislature, the Congress lost most seats from Andhra Pradesh to the Telegu Desam, despite the latter's novice status in national politics.
} 
votes, around 30 to 35 percent, it can move to a landslide victory in seats by gaining just a few percentage points in popular support. In many electoral districts it is possible for a candidate to win with just about 20 percent of the popular vote (Butler, Lahiri, and Roy 1995).

At the end of the day, it is really the number of seats in the legislature that matters for political control, so interest group politics to attain the critical number of votes from a large number of constituencies may be the key political strategy for all parties. Getting the critical number of votes to win a district may therefore be easier to accomplish with a strategy of targeted public expenditures towards pivotal coalitions of voters, and the cost of undertaking non-optimal levels of spending may be too diffuse across voters to translate into a substantial loss in electoral districts.

The relative importance of intergovernmental transfers and federal political institutions in explaining variation in subnational deficits is ultimately an empirical question. In the following section we lay out the empirical specification suggested by the analytical framework presented here, and test for the significance of political affiliation and central transfers in determining subnational deficits.

\section{Data, empirical specification, and results}

\section{Data}

The data set for this study is compiled from diverse sources for 15 major states of India over the period 1972-95. The political data is compiled from Butler, Lahiri, and Roy (1995). The public finance data on revenues, expenditures, and intergovernment transfers, is available from relevant volumes of the Reserve Bank of India Bulletin, a quarterly publication of the central bank of India with annual issues on details of finances of state governments. ${ }^{5}$ State demographic and economic characteristics, and a state-level price index to convert all variables into real terms are available from an Indian data set put together at the World Bank. A detailed description of these variables is available in Ozler, Datt, and Ravallion (1996). Table 1 provides summary statistics for each of the variables included in the analysis.

\footnotetext{
${ }^{5}$ I am grateful to Tim Besley of the London School of Economics and to Bhaskar Naidu of the World Bank's South Asia regional division for providing me with some of this data that had already been compiled in their research groups.
} 
Table 1. Summary Statistics ${ }^{a}$

\begin{tabular}{lccc}
\hline Variable & No. of Obs. & Mean & Std. Dev. \\
\hline $\begin{array}{l}\text { Political affiliation } \\
\text { (=1 if center and state govt. belong to same political }\end{array}$ & 360 & 0.62 & 0.49 \\
party) & & & \\
Affiliation * Seats & 360 & 0.47 & 0.41 \\
(1- Affiliation) * Seats & 360 & 0.15 & 0.26 \\
Coalition government & 360 & 0.16 & 0.37 \\
(=1 if state executive consists of a coalition govt.) & & & \\
State election year & 360 & 0.21 & 0.41 \\
(=1 in the year preceding a state election) & 360 & 4803.73 & 1807.98 \\
Real state income & 360 & 47396.79 & 28163.28 \\
Total population (in thousands) & 360 & 193.41 & 118.62 \\
Real fiscal deficit & 360 & 31.73 & 40.19 \\
Loans from the market (net) & 360 & 105.13 & 94.17 \\
Loans from the central government (net) & 348 & 55.41 & 48.45 \\
Planning Commission Grants & 352 & 173.32 & 64.80 \\
Finance Commission Transfers & 360 & 67.66 & 66.67 \\
Loans by the state government (net) & 360 & 843.95 & 364.71 \\
Spending (net of interest payments and loans) & 360 & 813.10 & 349.95 \\
Revenues & 360 & 3.32 & 10.25 \\
Growth & & \\
\hline a. Fiscal variables and state income are in per capita 1992 rupees & & \\
b. Fiscal Deficit = Total current expenditure + total capital expenditure - total revenue + (loans by state \\
government - recovery of loans).
\end{tabular}

These 15 states of India account for 95 percent of the total population. India consists of 26 states at present but many of the smaller ones have been created recently. However, 11 of the 15 states under study have existed since the organization of the federation in 1956. An additional two, were created for linguistic reasons out of a single large state-Maharashtra and Gujarat—in 1960; and two in 1966-Pubjab and Haryana—also for ethnic and linguistic reasons. Hence, in order to avoid issues of endogenous state boundaries, and of special transfers to some smaller states, we focus only on the 15 major states that have existed from the early days of the federation. ${ }^{6}$

\section{Specification}

The primary objective of this paper is to estimate the effect of intergovernmental grants and political affiliation between the center and a state government on the latter's fiscal deficit. The analytical framework developed in section 2 suggests that the effect of political affiliation and intergovernmental transfers should be estimated after controlling for general economic factors and other measures of political bargaining that affect the nationally optimal

\footnotetext{
${ }^{6}$ These 15 states are: Andhra Pradesh, Assam, Bihar, Gujarat, Haryana, Karnataka, Kerala, Madhya Pradesh, Maharashtra, Orissa, Punjab, Rajasthan, Tamil Nadu, Uttar Pradesh, and West Bengal. A sixteenth major state, Jammu and Kashmir, has been excluded because of the political uncertainties in the region that continue to this day.
} 
level $d$ of subnational deficits. We begin with the simplest specification for the effect of political affiliation:

$$
\text { DEFICIT }_{i t}=\beta \text { AFFILIATION }_{i t}+\eta Z_{i t}+\alpha_{i}+\delta_{t}+\varepsilon_{i t}
$$

where DEFICIT $_{i t}$ is the fiscal deficit in state $i$ in year $t$; AFFILIATION ${ }_{i t}$ is an indicator of political affiliation that equals 1 when the governing party in state $i$ at time $t$ belongs to the same party as that governing at the center at time $t$, and 0 otherwise. ${ }^{7}$ Time variant economic and demographic characteristics of states (state domestic product and total population) are included in the vector $Z_{i t}$, while $\alpha_{i}$ controls for state-level fixed effects, including the overall political importance of the state in the national legislature. In addition, a time effect for each year, $\delta_{t}$, is included to control for various shocks to the state economy in any given year. These additional variables need to be included because they are likely to be correlated with unobservable voter tastes and other shocks that affect both the political process of determining affiliation of the state government as well as fiscal deficits. Hence, $\beta$, the coefficient on political affiliation, is identified from variation within a state from its own average deficit when it is affiliated and not affiliated with the center. Under the hypothesis that the central government stands to make net gains in political support through augmented local public expenditures, we would expect to find $\beta>0$.

However, just including the affiliation indicator may not effectively identify the effect of partisanship because what may really matter is the proportion of seats from the state that the state ruling party controls in the national legislature. The affiliation indicator may be highly correlated with a large proportion of seats in the national legislature, as an affiliated state party may piggy-back on the voters' support of the national ruling party. We would thus need to include the variable measuring the proportion of seats from a state in the national legislature that is controlled by the state ruling party, as this could be an important measure of the state's political bargaining power. We also interact this variable with the affiliation indicator because our model would be consistent with differential effects of the proportion of seats in the national legislature held by the state ruling party in affiliated and non-affiliated states. In non-affiliated states, the proportion of seats to the national legislature held by the state ruling party would simply measure greater political bargaining power and thus be expected to have a positive effect on state deficits. However, in affiliated states if the proportion of seats held by the state ruling party is large or close to 1 , there may be limited or

\footnotetext{
7 The affiliation indicator is coded as equal to 1 if we are able to establish strict matching in party identity between the state and central government, that is, we ignore the role of political affiliation between loosely knit coalitions. This is the appropriate test for the model outlined in section II because it is more likely that local spending has spillover effects in national elections if voters are able to match party identities.
} 
negligible further gains to be had for the central government by extending additional funds for local spending programs. Instead, those affiliated states with a smaller proportion of seats controlled by the national ruling party may be politically pivotal to gain a majority in the national legislature, with greater marginal political benefits from additional public spending.

We therefore augment specification (1) by including interaction terms between affiliation and the proportion of seats (allotted to the state) controlled by the state ruling party in the national legislature-SEATS $S_{i t}$. We expect that if the center is indeed vulnerable to manipulation by rival political parties, $\gamma>0$, while a close interpretation of our model would lead us to expect $\phi<0$ :

$$
\begin{gathered}
\text { DEFICIT }_{i t}=\beta \text { AFFILIATION } \\
i t+\phi A F F I L * S E A T S_{i t}+\gamma(1-A F F I L) * S E A T S_{i t} \\
+\eta Z_{i t}+\alpha_{i}+\delta_{t}+\varepsilon_{i t}
\end{gathered}
$$

\section{Basic results}

Table 2 reports the results of estimating specifications (1) and (2) using ordinary least squares with robust standard errors. State governments that belong to the same political party as the central government have significantly higher fiscal deficits. Among affiliated states, those that control a small proportion of seats to the national legislature tend to have significantly higher deficits than those that control a higher proportion of seats. In fact, if an affiliated state government controls all the state's seats to the national legislature (that is, the proportion=1), then it's net benefit from affiliation becomes negative, since the coefficient on the interaction term is greater than the coefficient on the affiliation indicator. Hence, it is really those affiliated states where the center receives greater political gains at the margin that seem to be particularly favored in terms of being allowed to run higher deficits.

Table 2. Effect of political affiliation on state fiscal deficit (t-statistic in parenthesis)

\begin{tabular}{lcc}
\hline Variable & $(1)$ & $(2)$ \\
\hline Political affiliation & 18.50 & 69.59 \\
(=1 if center and state govt. belong to same political party) & $(1.95)$ & $(2.42)$ \\
Affiliation * Seats & -73.85 & $(-2.44)$ \\
& & -9.74 \\
(1- Affiliation)* Seats & $(-0.44)$ & 0.01 \\
& & $(1.68)$ \\
Real state income per capita & 0.01 & -0.002 \\
Total population & $(1.74)$ & $(-2.97)$ \\
& -0.002 & $\mathrm{~N}=360$ \\
\hline
\end{tabular}

Note: State fixed effects and year effects included; OLS regressions with robust standard errors; dependent variable is real fiscal deficit per capita 
The effect of political affiliation is substantial-from specification (1) it appears that affiliated states on average have a fiscal deficit that is 10 percent higher than the average of the sample. From specification (2) the fiscal deficit of affiliated states with the average proportion of seats in the national legislature is 12 percent higher than the sample average. Affiliated states whose ruling parties control less than half the proportion of seats have deficits that are more than 17 percent higher than the sample average. Non-affiliated states even with larger proportions of state seats in the national legislature do not appear to bargain for higher deficits.

\section{Robustness of the affiliation effect}

There are several potential problems with correctly identifying the effect of political affiliation on deficits in specifications (1) and (2), some of which are directly obtained from our strict definition of affiliation. First, the affiliation indicator may be correlated with instances of coalition governments at the state level when it is difficult to establish a strict party match with the central government. Such cases of coalition regimes are usually coded as 1 , that is not-affiliated, in our sample. But coalition politics is likely to have an impact on state deficits in its own right, so that the estimate of $\beta$ will be confounded with the effect of coalition politics. We could argue that to some extent the state fixed-effects, $\alpha_{i}$, accounts for the proclivity of a state to have coalition governments since some Indian states have been systematically more stable than others. However, we also include an additional indicator

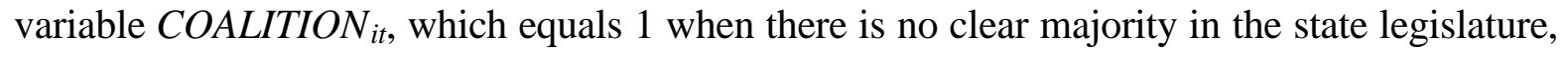
and the executive is formed of a coalition of various political parties.

Second, the timing of state elections could be correlated both with state deficits and with the affiliation indicator, and we therefore also include a specification that controls for the state election cycle. ${ }^{8}$ Third, the equation explaining variations in state deficits may be misspecified if it does not control for any dynamic process underlying deficits. Lagged deficits may be correlated both with current deficits and affiliation, and hence is also included to test the robustness of the affiliation effect.

We also test whether the effect of political affiliation changed during and after 1990, when the ruling party in the central government did not have a clear majority and required the support of a loosely knit coalition of political parties. It may be that political bargaining by coalition partners in (strictly) unaffiliated states began to surface after 1990, reversing the effect of affiliation on state deficits. This would be driven by a process of legislative bargaining (not modeled in section 2) where regional political parties may threaten to

\footnotetext{
${ }^{8}$ Although, Khemani (2000) finds no effect of elections on state debt. The election cycle only affects the composition of public spending.
} 
withdraw support from the ruling party coalition, leading to immediate dissolution of the government.

In Table 3 we include each of these additional variables whose omission may have potentially biased the coefficients on affiliation and its interactions in the results reported in the previous table. Coalition politics at the state level and the state election cycle are not significantly correlated with state deficits, and including them in the regression does not affect the size or significance of the coefficients of interest. This result is interesting in its own right because it seems to indicate that state- level political variables have no statistically discernable effect on deficits, although they might on the composition of spending and revenues (as reported by Khemani 2000). Instead, it is the state's political relation with the center that accounts for large variation in its deficit. The results of including an interaction variable for the effect of affiliation after 1990 indicates that political bargaining by unaffiliated states did not emerge even after the political weakening of single-party strength in the national legislature. We tried several specifications to test for the impact of emerging national coalition politics but found no significant change in subnational deficits during and after 1990 .

Table 3. Effect of political affiliation on state fiscal deficit (t-statistic in parenthesis)

\begin{tabular}{|c|c|c|}
\hline Variable & $(1)$ & $(2)$ \\
\hline Political affiliation & 78.03 & 56.24 \\
\hline \multirow[t]{2}{*}{ ( $=1$ if center and state govt. belong to same political party) } & $(2.32)$ & $(2.13)$ \\
\hline & -82.54 & -57.42 \\
\hline \multirow[t]{2}{*}{ Affiliation $*$ Seats } & $(-2.54)$ & $(-2.09)$ \\
\hline & -11.69 & -1.69 \\
\hline$(1-$ Affiliation $) *$ Seats & $(-0.51)$ & $(-0.09)$ \\
\hline Coalition government & -10.01 & \\
\hline (=1 if state executive consists of a coalition govt.) & $(-0.60)$ & \\
\hline State election year & -10.60 & \\
\hline (=1 in the year preceding a state election) & $(-0.92)$ & \\
\hline \multirow[t]{2}{*}{$(1-$ Affiliation) $*$ Years 1990-1995 } & $\begin{array}{c}10.37 \\
(0.43)\end{array}$ & \\
\hline & & 0.33 \\
\hline Real fiscal deficit per capita (lag 1) & & $\begin{array}{c}(3.58) \\
0.13\end{array}$ \\
\hline \multirow[t]{2}{*}{ Real fiscal deficit per capita (lag 2) } & & $(1.54)$ \\
\hline & 0.01 & 0.002 \\
\hline \multirow[t]{2}{*}{ Real state income per capita } & $(1.68)$ & $(0.45)$ \\
\hline & -0.002 & -0.001 \\
\hline \multirow[t]{3}{*}{ Total population } & $(-3.00)$ & $(-1.88)$ \\
\hline & $\mathrm{N}=360$ & $\mathrm{~N}=360$ \\
\hline & $\mathrm{R}$-sq $=0.71$ & $\mathrm{R}-\mathrm{sq}=0.76$ \\
\hline
\end{tabular}

Note: State fixed effects and year effects included; OLS regressions with robust standard errors; dependent variable is real fiscal deficit per capita 
Including lagged values of the deficit (in column 2) also does not change the effect of affiliation, although the size of the coefficient is reduced by 20 percent. ${ }^{9}$

\section{Intergovernmental transfers}

We now turn to the next issue of estimating the effect of intergovernmental transfers on subnational deficits. As discussed in section 2, greater dependence of state governments on intergovernmental transfers may create conditions for central bailouts of additional state deficits because otherwise the center would face large political costs from the state electorate. In addition, not including intergovernmental transfers in the previous specifications may have biased the coefficient on political affiliation if the affiliation effect on deficits is actually driven by its effect on systematic fiscal transfers from the center to the states, and it is really the design of these transfers that creates perverse incentives at the state level for higher fiscal deficit.

Khemani (2002) provides evidence that political affiliation between the center and the states affects the distribution of intergovernmental transfers in India in much the same way as its effect on fiscal deficits. Politically affiliated states receive greater transfers, creating for greater dependence on central transfers, and this dependence in its turn may encourage state governments to run higher deficits this period in expectation of higher transfers in the next period. Several scholars of intergovernment fiscal relations in India have long argued that states that receive higher federal transfers run higher deficits because of a purported "gapfilling" approach to transfers-where greater federal assistance is provided to states whose expenditure requirements are perceived to exceed their revenue potential (Rao 1998, McCarten, 2001).

However, we know of no study that actually tests this hypothesis with rigorous statistics - the link is made by simply describing the design of transfers and citing low revenue generation and high deficits at subnational levels. ${ }^{10}$ One reason why no one has actually estimated the effect of central transfers on state deficits may be because of the inherent simultaneity problem—deficits and transfers are determined in equilibrium and it is difficult to tease out a causal relation. Unfortunately, we are also not able to address this

\footnotetext{
${ }^{9}$ Including lagged values of the dependent variable in a panel data setting potentially creates for inconsistently estimated coefficients on all the variables. A Generalized Method of Moments (GMM) estimator that produces consistent estimates in dynamic panel data settings, using lagged values as instruments has been developed in the literature. However, at this time, we have not applied the GMM estimator to ensure that the affiliation effect is robust to that as well.

${ }^{10}$ Rajaraman (2000) is an exception, but she tests for the effect of grants to village governments on their own revenue generation in one state of India. But her specification does not really control for the endogenous determination of both transfers and local fiscal policies.
} 
endogeneity in a satisfactory manner, but make a first attempt to do so by estimating the effect of transfers using lagged values of transfers as instruments and in reduced form.

The constitutional assignment of revenue generation powers and expenditure responsibilities, and the role of different channels of central transfers to augment state resources is discussed at length in various studies (Rao and Singh 2000, and Anand, Bagchi, and Sen 2001). In a nutshell, the Indian federation is characterized by vertical fiscal imbalance, where the states undertake almost 60 percent of government expenditures, of which about 30 percent is financed by transfers from the central government (Rao and Singh 2001). There are two channels of general purpose transfers from the center to the states: tax sharing and grants decided by a statutory body, the Finance Commission, on the basis of wellestablished rules; and grants and loans decided by a semi-independent body, the Planning Commission, which is also based on an established formula. ${ }^{11}$

The results for intergovernmental transfers are reported in Table 4. The first column reports the reduced form with lagged values of Finance Commission transfers (share in taxes and statutory grants) and la gged values of Planning Commission grants, and the second column with predicted values using the lagged values as instruments. The third column reports the effect of the proportion of central transfers in total state revenues as a measure of state dependence. We find that contrary to the widespread opinion that the design of intergovernment transfers in India provides states with perverse incentives for fiscal management, greater transfers are actually correlated with lower deficits. The effect of affiliation is unchanged even after controlling for these transfers. ${ }^{12}$

\footnotetext{
${ }^{11}$ Various central ministries also make special purpose transfers for specific schemes and projects. These transfers are accompanied by strict conditionalities on the use of funds, and hence are excluded from this analysis, as they do not qualify as general budgetary transfers that increase resources available to state governments to use at their discretion.

${ }^{12} \mathrm{We}$ also estimate the effect of transfers on own revenue generation and do find a significant negative effect, but the effect is very small with the elasticity being less than 1 at the sample average. These results are available upon request.
} 
Table 4. Comparing effect of fiscal transfers versus political affiliation on state fiscal deficit

(t-statistic in parenthesis)

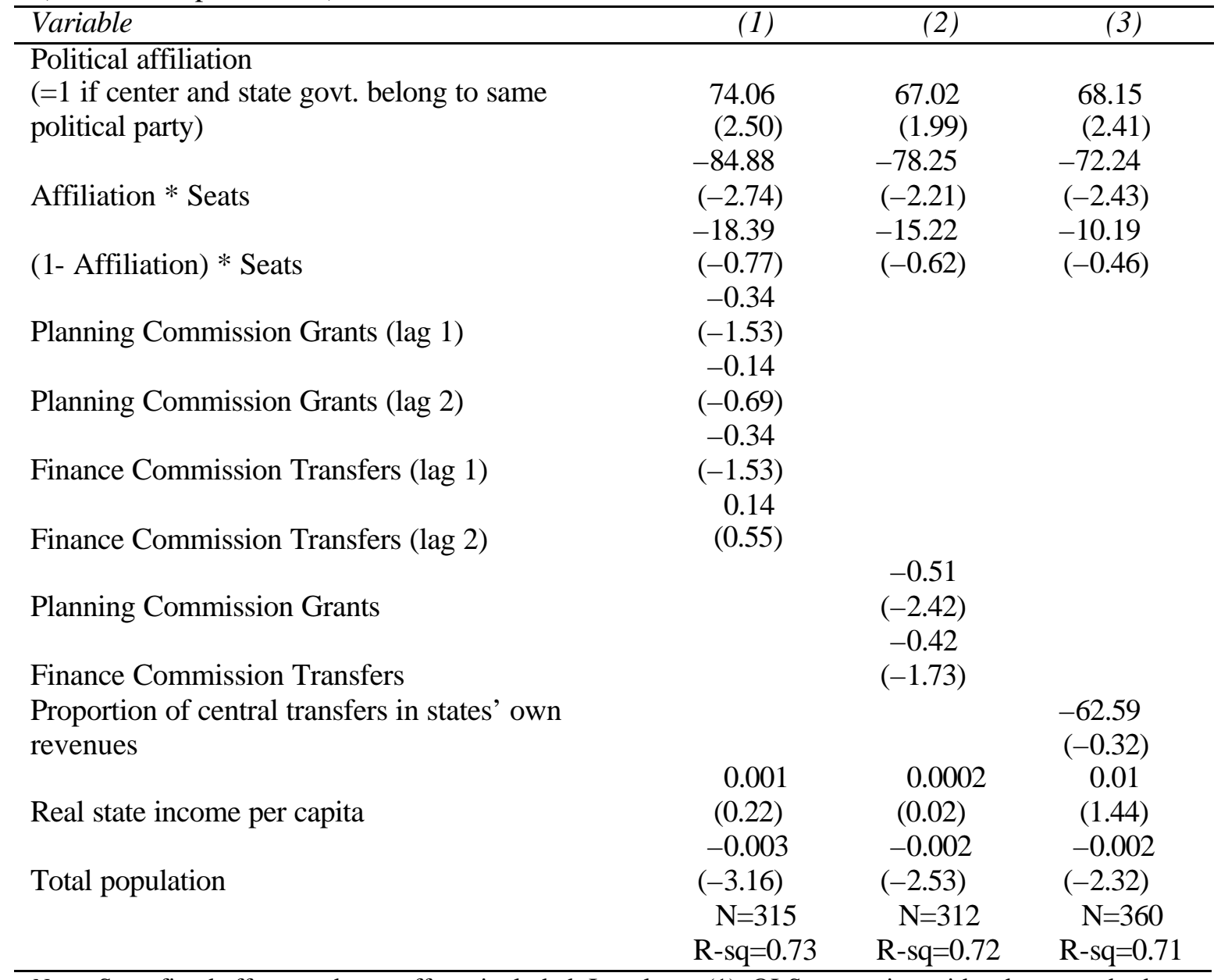

Note: State fixed effects and year effects included; In column (1), OLS regression with robust standard errors; in column (2) 2SLS regression with lagged values of transfers as instruments; dependent variable is real fiscal deficit per capita

\section{Financing the deficit}

It is also important to analyze how the higher deficit of affiliated states is financed. Perhaps affiliated state governments have higher credit worth and are more likely to raise and repay debt? This seems hardly credible since most of the financing of the deficit of state governments is through loans from the central government itself, with heavy regulation of market borrowing. However, it is widely believed that these regulations are easy to circumvent (Anand, Bagchi, and Sen 2001 and McCarten 2001) and at least in theory the Indian federation is susceptible to the risk of soft budget constraints at subnational levels. In fact, if the affiliation effect is driven by influential state leaders holding the central government hostage, we should probably expect to see the higher deficit financed by market loans that circumvent the center. In fact, as we report in Table 5, the higher deficit of 
affiliated states seems to be entirely financed by higher loans from the central government. Hence our interpretation of these results as the central government distributing deficits across states in much the same way as other federal transfers in accordance with its political objectives.

The above analysis also suggests that the additional deficits of politically affiliated states may not be the result of costly fiscal bargaining between the center and the state, as assumed in the strategic game laid out in section 2 with first mover advantages for provincial governments. The additional deficits of affiliated states may in fact be the outcome of centrally determined regional resource allocation through grants and loans, where political considerations result in greater resource allocation to affiliated states. Khemani (2002) develops a model of central resource allocation where the solution is characterized by greater central transfers to affiliated states.

Table 5. Financing the deficit: Effect of political affiliation on loans from the central government

(t-statistic in parenthesis)

\begin{tabular}{lcc}
\hline Variable & $(1)$ & $(2)$ \\
\hline Political affiliation & 16.79 & 76.90 \\
(=1 if center and state govt. belong to same political party) & $(2.07)$ & $(2.62)$ \\
& & -71.89 \\
Affiliation * Seats & & $(-2.11)$ \\
& & 17.69 \\
(1- Affiliation) * Seats & $(1.13)$ \\
& 0.03 & $(3.69)$ \\
Real state income per capita & $(3.68)$ & -0.001 \\
& -0.001 & $(-1.35)$ \\
Total population & $(-1.39)$ & $\mathrm{N}=360$ \\
& $\mathrm{~N}=360$ & $\mathrm{R}-\mathrm{sq}=0.54$ \\
\hline
\end{tabular}

Note: State fixed effects and year effects included; OLS regressions with robust standard errors; dependent variable is net loans from the central government to the state.

However, a question still arises: why does the effect of political affiliation on resource transfer to state governments work through deficits financed by central loans rather than solely through the systematic channels of intergovernmental grants? The answer probably lies in additional political discretion and control over loans to state governments, since other channels of resource transfers are more rules-based and controlled by statutory bodies. Khemani (2002) contrasts the effect of political variables on different channels of transfers and shows that the transfers determined by some agencies are more amenable to control by the national political executive. The major part of central loans to state governments are in fact determined by direct participation of the national political executive in the decisionmaking process. 


\section{Political bargaining through extra-budgetary transactions?}

The analysis undertaken here is based on budgetary transactions of state governments for which detailed data is compiled by government agencies on a regular basis. There is concern among policy circles that political factors may in fact have a more powerful influence on extra-budgetary transactions that are not subjected to legislative scrutiny. One channel of particular concern is the debt of state-owned public sector enterprises (PSEs), particularly in the power sector, that is guaranteed by the state government and owed either to a nationalized banking sector or to other central government agencies. It is therefore possible that nonaffiliated states are able to extract greater resources from the central government through the borrowings of their public enterprises that are, in effect, never paid back.

We do not have state level data available on public sector enterprises to check this alternate story of political bargaining between the center and the states. However, one variable we do have data for that would perhaps approximate the borrowing of PSEs is that of loans and advances by the state government which are reported to consist largely of loans to publicly owned enterprises. We find that the effect of political affiliation on such loans and advances by the state government is of similar sign and magnitude as the effect on overall fiscal deficit. Net loans by affiliated state governments is about 9 percent higher than that by non-affiliated state governments, as reported in Table 6. This evidence, and the fact that we do not find any effect of political affiliation on the market debt for which data is available through state budgets, and that we do indeed find substantial political effects on other budgetary transactions (thereby suggesting that legislative scrutiny does not prevent political manipulations from taking place), leads us to speculate that any marginal effect of political affiliation on the finances of state owned enterprises would be similar to the effects described here.

Table 6. Effect of political affiliation on loans and advances by the state government (t-statistic in parenthesis)

\begin{tabular}{lcc}
\hline Variable & $(1)$ & $(2)$ \\
\hline Political affiliation & 5.55 & 36.47 \\
(=1 if center and state govt. belong to same political party) & $(0.89)$ & $(2.27)$ \\
& & -49.20 \\
Affiliation * Seats & & $-2.86)$ \\
& & -14.64 \\
$(1-$ Affiliation) * Seats & -0.01 & $(-1.16)$ \\
& $(1.58)$ & -0.01 \\
Real state income per capita & -0.001 & $-1.73)$ \\
& $(-1.40)$ & $(-1.34)$ \\
Total population & $\mathrm{N}=360$ & $\mathrm{~N}=360$ \\
& $\mathrm{R}-\mathrm{sq}=0.61$ & $\mathrm{R}-\mathrm{sq}=0.62$ \\
\hline
\end{tabular}

Note: State fixed effects and year effects included; OLS regressions with robust standard errors; dependent variable is net loans and advances made by the state government. 


\section{Effect on subnational spending}

What is the underlying structural model that leads to greater deficits for affiliated states? Following Alt and Lowry (1994) and Jones, Sanguinetti, and Tommasi (2000) we estimate structural equations for state revenues and expenditure using three stage least squares:

$$
\begin{aligned}
& \text { REVENUE }_{i t}=\eta_{1} \text { INCOME }_{i t}+\eta_{2} \text { POPU }_{i t}+\eta_{3} \text { REVENUE }_{i t-1}+\eta_{4} \text { TRANSFER }_{i t-1} \\
& +\eta_{5} \text { DEFICIT }_{i t-1}+\beta_{r} \text { AFFILIATION }_{i t}+\phi_{r} \text { AFFIL }^{*} \text { SEATS }_{i t}+\gamma_{r}\left(1-\text { AFFIL }^{*} \text { SEATS }_{i t}\right. \\
& +\lambda_{r} \text { COALITION }_{i t}+\alpha^{r}{ }_{i}+\delta^{r}{ }_{t}+\varepsilon^{r}{ }_{i t} \\
& \text { SPENDING }_{i t}=\mu_{1} \text { REVENUE }_{i t}+\mu_{2} \text { POPU }_{i t}+\mu_{3} \text { GROWTH }_{i t}+\mu_{4} \text { TRANSFER }_{i t-1} \\
& +\mu_{5} \text { DEFICIT }_{i t-1}+\beta_{S} \text { AFFILIATION }_{i t}+\phi_{S} \text { AFFIL } * S E A T S_{i t}+\gamma_{S}(1-\text { AFFIL)*SEATS } i t \\
& +\lambda_{S} \text { COALITION }{ }_{i t}+\alpha^{S}{ }_{i}+\delta^{S}{ }_{t}+\varepsilon^{S}{ }_{i t}
\end{aligned}
$$

where REVENUE $E_{i t}$ is the total per capita revenues of state $i$ in year $t$, and $\operatorname{SPENDING}_{i t}$ is total spending undertaken by state $i$ in year $t$ (net of interest payments and loans and advances by the state government).

The estimated parameters for the equations above are reported in Table 7. The pattern of coefficients is consistent with those in the deficit regressions in previous tables. Spending by affiliated state governments is 5 percent higher on average, although those affiliated governments that control a higher proportion of the state's seats in the national legislature have lower spending. Interestingly, states ruled by coalition governments lower spending by 4 percent. Grants from the central government have a negative effect on state spending, once total revenues are controlled for, again contrary to the widely hypothesized view that the structure of intergovernment grants creates perverse incentives for greater spending and higher deficits. 
Table 7. Structural Equations for Revenues and Spending of State Governments

\begin{tabular}{lcc} 
(z-statistic in parenthesis) & Revenues & Spending \\
\hline Variable & 0.053 & \\
Real state income per capita & $(5.39)$ & 1.03 \\
& & $(16.26)$ \\
Revenues & -0.12 \\
& & $(-0.29)$ \\
Growth & -0.01 & 0.001 \\
& $(-4.30)$ & $(0.72)$ \\
Total population & 0.36 & \\
Revenues (lag 1) & $(6.99)$ & -0.41 \\
& -0.02 & $(-3.14)$ \\
Planning Commission Grants (lag 1) & $(-0.11)$ & 0.03 \\
& -0.49 & $(0.20)$ \\
Finance Commission Transfers (lag 1) & $(-2.64)$ & 0.27 \\
& 0.02 & $(5.02)$ \\
Deficit (lag 1) & $(0.29)$ & 40.86 \\
Political affiliation & 2.70 & $(2.01)$ \\
(=1 if center and state govt. belong to same political party) & $(0.09)$ & -44.67 \\
& -21.84 & $(-2.04)$ \\
Affiliation * Seats & $(-0.69)$ & 3.78 \\
& -0.16 & $(0.18)$ \\
(1- Affiliation) * Seats & $(-0.01)$ & -31.59 \\
Coalition government & -25.74 & $(-2.18)$ \\
(=1 if state executive consists of a coalition govt.) & $(-1.25)$ & $\mathrm{N}=332$ \\
& $\mathrm{~N}=332$ & $\mathrm{R}-\mathrm{sq}=0.98$ \\
\hline
\end{tabular}

Note: State fixed effects and year effects included; 3SLS regression.

\section{Conclusion}

This paper conducts a simple test of the common-pool game in a federation where subnational governments are more likely to have higher deficits because they do not internalize the macroeconomic effects of fiscal profligacy. Specifically, we test two predictions implied by this model that subnational governments that belong to the same political party as the central government should have lower fiscal deficits because they are more likely to internalize the effect of increasing deficits; and that states that are more dependent on intergovernmental transfers should have higher fiscal deficits because of the greater disconnect between revenues and spending. We find that in 15 major states of India over the period 1972-95, states in fact have substantially higher deficits (about 10 percent of the sample average) when their government belongs to the same party governing at the center. The additional deficit of affiliated states is financed almost entirely by additional loans from the central government (as opposed to the market) leading to our interpretation that political 
considerations influence the distribution of deficits across states in a similar manner to other fiscal transfers.

In order to explicitly test for the relative importance of the design of intergovernmental grants versus political variables, we estimate (for the first time in the literature, to the best of our knowledge) the effect of different categories of grants on state deficits in India. We find no evidence for the widely held view that the design of intergovernment transfers in India provides perverse incentives to state governments to run higher deficits. There is no substantial effect of transfers on deficits (in fact a small and counter-intuitive negative effect), and a robust effect of political affiliation on deficits that holds for a range of specifications. The evidence provided here thus suggests that subnational deficits are determined by the nature of electoral competition between political parties, and as long as the rules of fiscal federalism do not change the nature of party competition in the federation, they may have limited independent effect on the consolidated government deficit.

The policy implication is that formal rules regulating fiscal relations in federations have limited ability for substantial impact on government deficits if political incentives allow and encourage circumventing these rules. Further research into the role of political institutions and electoral rules may provide insight into whether these institutions can be changed to provide better incentives for fiscal prudence, or how other institutional rules can be designed to be impervious to political compulsions. A comparative analysis of political determinants of budget deficits in developing countries, at both the national and subnational levels, would be valuable in underpinning discussions of potential institutional reforms that both encourage governments to be fiscally responsible and are resistant to political manipulation.

\section{References}

The word "processed" describes informally reproduced works that may not be commonly available through library systems.

Aizenman, J. 1998. "Fiscal discipline in a union.” In F. Sturzenegger and M. Tommasi, eds., The Political Economy of Economic Reforms. Cambridge, Mass.: MIT Press.

Alesina, A., and R. Perotti. 1995. "The political economy of budget deficits." IMF Staff Papers (March): 1-31.

Alesina, A., and R. Perotti. 1996. "Budget deficits and budget institutions." Harvard University. Processed.

Alt, J., and R. Lowry. 1994. "Divided government, fiscal institutions, and budget deficits: evidence from the state." The American Political Science Review 88(4): 811-28.

Anand, M., A. Bagchi, and T. Sen. 2001. "Fiscal discipline at the state level: perverse incentives and paths to reform." Paper presente d at conference on "India: Fiscal Policies to Accelerate Economic Growth.” New Delhi, May 21-22. 
Butler, D., A. Lahiri, and P. Roy. 1995. “India Decides: Elections 1952-1995.” New Delhi.

Chhibber, P. 1995. "Political parties, electoral competition, government expenditures and economic reform in India." The Journal of Development Studies 32(1): 74-96.

Cox, G., and M. McCubbins. 1986. "Electoral politics as a redistributive game." The Journal of Politics 48: 370-89.

Dasgupta, S., A. Dhillon, and B. Dutta. 2001. "Electoral goals and center-state transfers in India." Working paper [Retrieved on April 18, 2002 from www.warwick.ac.uk/economics/dutta/]

Dixit, A., and J. Londregan. 1995. "Redistributive politics and economic efficiency." American Political Science Review 89: 856-66.

Dixit, A., and J. Londregan. 1996. "The determinants of success of special interests in redistributive politics." The Journal of Politics 58: 1132-55.

Dixit, A., and Londregan, J., 1998. "Ideology, tactics, and efficiency in redistributive politics." Quarterly Journal of Economics 113: 497-529.

Inman, R. 2001. "Transfers and bailouts: enforcing local fiscal discipline with lessons from US federalism.” In J. Rodden. G. Eskeland, and J. Litvack, J., eds., Decentralization and Hard Budget Constraints. MIT Press (forthcoming).

Inman, R., and M. Fitts. 1990. "Political institutions and fiscal policy: evidence from the US historical record." Journal of Law Economics, and Organization 6: 79-132.

Jones, M., P. Sanguinetti, and M. Tommasi. 2000. "Politics, institutions, and fiscal performance in a federal system: an analysis of the Argentine provinces." Journal of Development Economics 61: 305-33.

Khemani, S. 2000. "Political Cycles in a Developing Economy: effect of elections in the Indian States." Policy Research Working Paper 2454 (September). World Bank, Development Research Group, Washington, D.C.

Khemani, S. 2002. "Partisan Politics and Intergovernmental Transfers in India." World Bank, Development Research Group, Washington, D.C. Processed.

McCarten, W., 2001. "The challenge of fiscal discipline in the Indian states.” In J. Rodden. G. Eskeland, and J. Litvack, J., eds., Decentralization and Hard Budget Constraints. MIT Press (forthcoming).

Ozler, B., G. Datt, and M. Ravallion. 1996. "A Database on Poverty and Growth in India." Development Research Group, World Bank, Washington, D.C. [Retrieved April 18, 2002 from http://www.worldbank.org/poverty/data/indiapaper.htm]

Poterba, J. 1994. "State responses to fiscal crises: the effects of budgetary institutions and politics." Journal of Political Economy 102: 799-821.

Poterba, J. 1996. "Budget institutions and fiscal policy in the US states." American Economic Review 86: $395-400$.

Rajaraman, I., and G. Vashishtha. 2000. "Impact of grants on tax effort of local government", Working Paper No. 1. National Institute of Public Finance and Policy (India), New Delhi.

Rao, G. 1998. "India: intergovernmental fiscal relations in a planned economy.” In Richard M. Bird and Francois Vaillancourt, eds., Fiscal Decentralization in Developing Countries. Cambridge: Cambridge University Press.

Rao, G., and N. Singh. 2000. "The political economy of center-state fiscal transfers in India.” Paper presented at the Columbia University-World Bank Conference on Institutional Elements of Tax Design and Reform, February 18-19, 2000. 
Reserve Bank of India. "Reserve Bank of India Bulletin, 1960-1999."

Rodden, J., 2000. "And the last shall be first: Federalism and deficits in Germany." MIT. Processed.

Rodden, J., 2002. "The dilemma of fiscal federalism: intergovernmental grants and fiscal performance around the world." American Journal of Political Science (forthcoming)

Rodden, J., G. Eskeland, and J. Litvack, eds. 2001. Decentralization and Hard Budget Constraints. MIT Press (forthcoming).

Rogers, D. and Rogers, J., 2000. "Political competition and state government size: do tighter elections produce looser budgets?" Public Choice 105: 1-21.

Snyder, J., 1989. "Election goals and the allocation of campaign resources.” Econometrica 57: 637-60.

Ter-Minassian, T., ed. 1997. Fiscal Federalism in Theory and Practice: A Collection of Essays. Washington, D.C.: International Monetary Fund.

Treisman, D., 1999. "Political decentralization and economic reform: a game-theoretic analysis", American Journal of Political Science 43: 488-517.

von Hagen, J. 1992. "Budgeting procedures and fiscal performance in the European Communities." Economic Paper 26. European Commission.

Weiner, M., and J. Field, eds. 1974. Studies in electoral politics in the Indian states. Delhi: Manohar Book Service.

Weingast, B., K. Shepsle, and C, Johnsen. 1981. "The political economy of benefits and costs: a neoclassical approach to distributive politics." Journal of Political Economy 89: 642-64.

World Bank. 1999. "Beyond the Center: Decentralizing the State.” Report 19636. Latin American and Caribbean Studies, Viewpoints series. World Bank, Washington, D.C. 